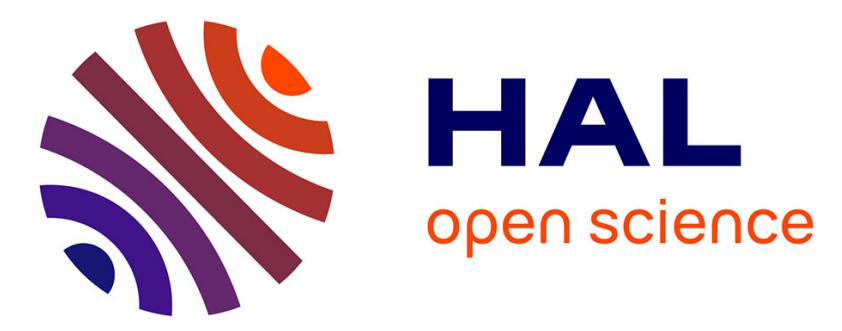

\title{
3-D Numerical Hybrid Method for PM Eddy-Current Losses Calculation: Application to Axial-Flux PMSMs
}

Raouf Benlamine, Frédéric Dubas, Sid-Ali Randi, Dominique Lhotellier, Christophe Espanet

\section{- To cite this version:}

Raouf Benlamine, Frédéric Dubas, Sid-Ali Randi, Dominique Lhotellier, Christophe Espanet. 3D Numerical Hybrid Method for PM Eddy-Current Losses Calculation: Application to Axial-Flux PMSMs. IEEE Transactions on Magnetics, 2015, 51, pp.8106110. 10.1109/TMAG.2015.2405053 . hal-01184649

\author{
HAL Id: hal-01184649 \\ https://hal.science/hal-01184649
}

Submitted on 17 Aug 2015

HAL is a multi-disciplinary open access archive for the deposit and dissemination of scientific research documents, whether they are published or not. The documents may come from teaching and research institutions in France or abroad, or from public or private research centers.
L'archive ouverte pluridisciplinaire HAL, est destinée au dépôt et à la diffusion de documents scientifiques de niveau recherche, publiés ou non, émanant des établissements d'enseignement et de recherche français ou étrangers, des laboratoires publics ou privés. 


\title{
3-D Numerical Hybrid Method for PM Eddy-Current Losses Calculation: Application to Axial-Flux PMSMs
}

\author{
R. Benlamine ${ }^{1}$, Student Member, IEEE, F. Dubas ${ }^{1 *}$, S-A. Randi ${ }^{2}$, D. Lhotellier ${ }^{2}$, and C. Espanet ${ }^{1}$, Member, IEEE \\ ${ }^{1}$ ENERGY Department, University of Franche-Comté (UFC), FEMTO-ST Institute (UMR CNRS 6174), Belfort, France \\ ${ }^{2}$ Renault Technocenter, 1 Avenue du Golf, Guyancourt, France
}

\begin{abstract}
This paper describes a three-dimensional (3-D) numerical hybrid method (NHM) of the permanent-magnet (PM) eddy-current losses in axial-flux PM synchronous machines (PMSMs). The PM magnetic flux density is determined by using the multi-static 3D finite-element method (FEM) at resistance-limited (i.e., without eddy-current reaction field). Based on the predicted flux density distribution, the eddy-currents induced in the PMs and the 3-D PM eddy-current losses are calculated by 3-D finitedifference method (FDM) considering a large mesh. The 3-D calculation model is then based on a coupling between the multistatic 3-D FEM at resistance-limited and 3-D FDM. Two 24-slots/16-poles (i.e., fractional-slot number) axial-flux PMSMs having a non-overlapping winding (all teeth wound type) with stator double-sided structure are studied: i) Surface-PM (SPM), and ii) interior-PM (IPM). To evaluate the reliability of the proposed technique, the 3-D PM eddy-current losses are determined and compared to transient 3-D FEM (i.e., magneto-dynamical 3-D FEM). The computation time can be divided by 25 with a difference less than $12 \%$.
\end{abstract}

Index Terms_Axial-flux, eddy-current, finite-difference, finite-element, permanent-magnet (PM) machines, resistance-limited.

\section{INTRODUCTION}

\section{A. $\quad$ Context of the Work}

$\mathrm{T}$ HE PMSMs have become the most interesting choice for electric powertrains in automotive applications, mainly the electric/hybrid/fuel cell vehicles (EVs/HEVs/FCVs). This is due to their high torque/power and torque/power density performances [1]. However, the PMs used in the electric machines, especially rare-earth (i.e., $\mathrm{NdFeB}$ or $\mathrm{SmCo}$ ), are sensitive to temperature, which may cause their partial/irreversible demagnetization. The increase of PM temperature is due to local eddy-current losses caused by magnetic flux density harmonics which are not synchronous with the rotor rotational speed [2]-[6]. At noload (i.e., at $I=0 \mathrm{~A}$ with $I$ the RMS value of stator current), the eddy-current losses are caused by the reluctance variation due to the stator slot-openings [2] and [6]. On load (i.e., at $I \neq 0 \mathrm{~A}$ ), these rotor losses result from both stator slotting permeance harmonics and magnetomotive force (MMF) harmonics which are of two types [3]-[5]:

MMF harmonics caused by the discrete positions of stator winding conductors;

MMF harmonics caused by time harmonics in the stator current (e.g., sinusoidal, six-step rectangular,..., PWM currents).

The PM eddy-current losses, caused by these nonsynchronous magnetic fields, are a well known problem in PMSMs design. Hence, the ability to predict these losses is very important for the machine designers in order to:

- maximize the machine performances, such as efficiency and torque/power density;

- predict the thermal behavior of the machine for critical operating points, especially PM heating.

\footnotetext{
${ }^{*}$ Corresponding author: F. Dubas (email: FDubas@gmail.com). Digital Object Identifier inserted by IEEE
}

Different PM eddy-current losses calculation models and methods have been developed. A literature review on eddycurrent loss calculations can be found in [4]-[6], and their references. The PM eddy-current losses can be calculated [4]-[43]:

- (semi-)analytically or numerically;

- with a slotless or slotted stator structure;

- in PMSMs equipped with surface-mounted, surface-inset or interior PMs with or without skewed PM;

- with radial, parallel, axial, tangential or Halbach magnetization pattern;

- in rectangular, trapezoidal or circular PM shapes;

- only with the PM magnetic field, the armature reaction field or both;

- with a two-dimensional (2-D) or 3-D model formulated in Cartesian or cylindrical coordinates; with or without the saturation effect;

with or without considering the current penetration effect on the PMs (i.e., resistance-limited or skinlimited).

The PM losses can be estimated from experimental measurement using the loss segregation or thermometric methods [4] and [7]-[19]. In order to reduce these losses, the PM of each pole can be segmented circumferentially, radially and/or axially [9]-[11], [14] and [20]-[25]. Moreover, by embedding PM in the rotor core, PM eddycurrent losses can be reduced [10], [11], [22] and [44].

It makes sense to use 2-D FEM [2]-[7], [18]-[21] and [29][35] or (semi-)analytical equations [2]-[6], [12], [18], [20], [25], [29]-[32] and [36] to calculate the PM eddy-current losses in electric machine modeling. But the 2-D calculations ignore end-effects, causing a large error in the PM eddycurrent losses. The calculation of PM eddy-current losses in multi-phase/-pole PMSMs is a 3-D problem by its nature, because the eddy-currents are circulating along loops inside the PM volume. The 3-D analytic calculations are possible in few geometries with 3-D complex models [8], [13], [19], [21], [23], [24], [27] and [33]-[35], or by using simple 2-D/3- 
D mathematical coefficients to correct the results of 2-D models [21], [23], [24] and [37]-[39]. The most accurate models are the 3-D FEM [9]-[13], [15], [19], [22] and [23][28]. Nevertheless, since the induced eddy-currents can be highly not uniformly distributed, it should be noted that a fine mesh discretization may be necessary to accurately model skin effect, which, in turn, may lead to numerical instability issues [43]. However, these methods are very time and memory consuming, in particular for 3-D geometry, due to the combination of the magnetic non-linearity, the computation of the eddy-currents, and the requirement to model the relative movement between the rotor and the stator. Besides, the numerical techniques do not have the advantage to be sufficiently explicit in comparison with analytical equations. Therefore, they can hardly be used in iterative motor design optimizations and initial design procedures where several parameters change in wide ranges, but allow analyze the detailed performance of previously engineered machine (i.e., for design verification). Nevertheless, in the literature, it is possible to optimize electromagnetic systems from numerical methods [45]-[47].

Nowadays, in order to reduce the computation time, hybrid methods can be developed [14] and [40]-[42]. In [14] and [41], Vansompel $\boldsymbol{e t}$ al. propose a multilayer 2-D-2-D coupled method for a SPM axial-flux machine. The method is based on the calculation of the one-dimensional air-gap flux density distribution using multi-static 2-D FEM. The 2D PM flux density distributed is then built to be used in a time harmonic 2-D FEM in order to calculate the 3-D PM eddy-current losses. The results are compared with those obtained by transient 3-D FEM. In [40], Zhang et al. develop a hybrid method by combining the magnetostatic 2-D FEM with a 3-D analytical model of induced eddy-currents in the PM. The 3-D eddy-current losses have been calculated in the IPM radial-flux machine. The hybrid method has been compared to 2-D and 3-D FEM. In [42], Okitsu et al. propose a coupled 2-D and 3-D eddy-current analysis with the FEM. The flux density distribution obtained from the 2-D magnetostatic FEM of the SPM motor has been used in 3-D numerical model of only a PM, in order to evaluate the 3-D PM eddy-current losses in the SPM motor. The results have been compared with those obtained by transient 3-D FEM. In this present paper, 3-D PM eddy-current losses will be calculated using a numerical hybrid method (NHM) applied to axial-flux PMSMs.

According to [48]-[50], and their references, the growing interest for the axial-flux electrical machines since the last two decades can be explained by the high performances of these machines. Comparing to conventional electrical machines (e.g., radial/transverse-flux machines, hybrid excitation synchronous machines...) [51]-[56], the axialflux PMSMs have a number of distinct advantages:

- higher torque/power-to-volume/weight ratios;

- higher efficiency;

- $\quad$ easily adjustable air-gaps (i.e., without modifying stator and rotor structure);

less noise and vibration levels;

better removing of the heating in the stator;

lower rotor moment of inertia;

lower end winding lengths; smaller in size than their radial-flux counterparts; best suited machines for applications where the axial space is limited (e.g., in EVs/HEVs/FCVs).

The axial-flux PMSM can be integer or fractional-slot number with three/multi-phases having stator winding patterns: distributed (i.e., overlapping), concentrated (i.e., non-overlapping), toroidal or ring-shaped. The fractional-slot non-overlapping winding, comparing to overlapping winding, has lower end-windings which decreases copper losses and thus increases efficiency. The cogging and torque ripple are reduced as well [1] and [57]-[58]. Also, it is easier to manufacture. However, the MMF is rich in spatial harmonics, which may increase PM eddy-current losses [59].

\section{B. Objectives of the Paper}

The work in this paper takes part in the development and improvement of 3-D NHM for determining the 3-D PM eddy-current losses in PMSMs. This method can be applied to different 3-D machines (i.e., radial, axial or transversalflux PMSMs). Section II describes the 3-D calculation method of the PM eddy-current losses which is then based on a coupling between the multi-static 3-D FEM at resistance-limited and 3-D FDM. The PM magnetic flux density is determined by the multi-static 3-D FEM at resistance-limited (i.e., without eddy-current reaction field). Based on the predicted flux density distribution, the eddycurrents induced in the PMs and the PM eddy-current losses are calculated by 3-D FDM considering a large mesh. In this paper, the 3-D NHM of the PM eddy-current losses has been applied in section III to two 24-slots/16-poles (i.e., fractional-slot number) axial-flux PMSMs having a nonoverlapping winding (all teeth wound type) with stator double-sided structure for: i) SPM, and ii) IPM machines. The studied machines are described in this section. To evaluate the reliability of the proposed technique, the 3-D PM eddy-current losses are determined and compared to the ones obtained with transient 3-D FEM (i.e., magnetodynamical 3-D FEM) [60]. Finally, the computation time and precision are analyzed.

\section{3-D NUMERICAL HYBRID METHOD OF PM EDDY- CURRENT LOSSES}

\section{A. List of Assumptions}

In the analysis, the following assumptions are considered:

- only rectangular PM shapes [see Fig. 1 with $\overrightarrow{u_{x}}$, $\overrightarrow{u_{y}}, \overrightarrow{u_{z}}$ ) the unit vectors of PM local axis system];

- the PM magnetic flux density is determined by the 3-D FEM at resistance-limited (i.e., by neglecting the electrical conductivity $\sigma_{m}$ of the PMs);

- $\quad$ only the PM flux density component according the PM magnetization direction is considered for the induced eddy-currents in the PMs: $\overrightarrow{B_{x}}$ and $\overrightarrow{B_{y}}$ are neglected then $\vec{B}=\left\{0,0, B_{z}\right\}$;

- the electric field in the PMs has two components: $\vec{E}=\left\{E_{x}, E_{y}, 0\right\}$;

- the 3-D mesh grid in the PMs [see Fig. 1] for FDM is uniform (i.e., the same elementary volumes are considered). 


\section{B. Calculation Method Equations}

1) Governing Partial Differential Equations for the Electrical Field: In order to derive to governing partial differential equations (PDEs), and by assuming that the term $\partial \vec{D} / \partial t$ is negligible in comparison with the resultant eddy-current density $\vec{J}=\left\{J_{x}, J_{y}, 0\right\}$, the Ohm's law

$$
\vec{J}=\sigma_{m} \cdot \vec{E}
$$

the Ampere's law

$$
\overrightarrow{\operatorname{rot}(\vec{H})}=\vec{J} \quad \text { implying } \operatorname{div}(\vec{J})=0
$$

and the Faraday's law for magnetism

$$
\overrightarrow{\operatorname{rot}(\vec{E})}=-\frac{\partial \vec{B}}{\partial t}
$$

of Maxwell's equations are used.

Using (1) (3), the governing PDEs for the electrical field, in Cartesian coordinates, can be defined by

$$
\begin{gathered}
\frac{\partial^{2} E_{y}}{\partial x^{2}}+\frac{\partial^{2} E_{y}}{\partial y^{2}}=-\frac{\partial^{2} B_{z}}{\partial x \partial t} \\
\frac{\partial E_{x}}{\partial x}=-\frac{\partial E_{y}}{\partial y}
\end{gathered}
$$

2) Solving of PDEs using 3-D FDM: The solution of (4) and (5) will be obtained with FDM. Fig. 1 shows the 3-D mesh grid in the PM with $(i, j, k)$ the indexes of the mesh nodes in the PM local axis system (i.e., $i$ for $x$-axis, $j$ for $y$ axis, and $k$ for $z$-axis) where $h_{x}, h_{y}$ and $h_{z}$ are respectively the mesh heights in the various axes. For each point of the grid, the terms of (4) and (5) can be expressed by

$$
\begin{aligned}
& \frac{\partial E_{x}}{\partial x}=\frac{E_{x_{i+1, j, k}}^{t}-E_{x_{i, j, k}}^{t}}{h_{x}} \\
& \frac{\partial E_{y}}{\partial y}=\frac{E_{y_{i, j+1, k}}^{t}-E_{y_{i, j, k}}^{t}}{h_{y}} \\
& \frac{\partial^{2} E_{y}}{\partial x^{2}}=\frac{E_{y_{i+1, j, k}}{ }^{t}-2 \cdot E_{y_{i, j, k}}^{t}+E_{y_{i-1, j, k}}{ }^{t}}{h_{x}{ }^{2}} \\
& \frac{\partial^{2} E_{y}}{\partial y^{2}}=\frac{E_{y_{i, j+1, k}}^{t}-2 \cdot E_{y_{i, j, k}}^{t}+E_{y_{i, j-1, k}}^{t}}{h_{y}{ }^{2}} \\
& \frac{\partial^{2} B_{z}}{\partial x \partial t}=\frac{\left(B_{z}^{t+\Delta t}{ }_{i+1, k}-B_{z_{i, j, k}}^{t+\Delta t}\right)-\left(B_{z i+1, j, k}^{t}-B_{z i, j, k}^{t}\right)}{h_{x} \cdot \Delta t}
\end{aligned}
$$

By using (6) (10), (4) is defined by

$$
\begin{gathered}
a \cdot E_{y_{i, j, k}}^{t}+b \cdot\left(E_{y_{i, j+1, k}}^{t}+E_{y_{i, j-1, k}}^{t}\right) \\
\ldots+c \cdot\left(E_{y_{i+1, j, k}}^{t}+E_{y_{i-1, j, k}}^{t}\right)= \\
d \cdot\left(B_{z i, j, k}^{t+\Delta t}-B_{z i+1, j, k}^{t+\Delta t}+B_{z i+1, j, k}^{t}-B_{z i, j, k}^{t}\right)
\end{gathered}
$$

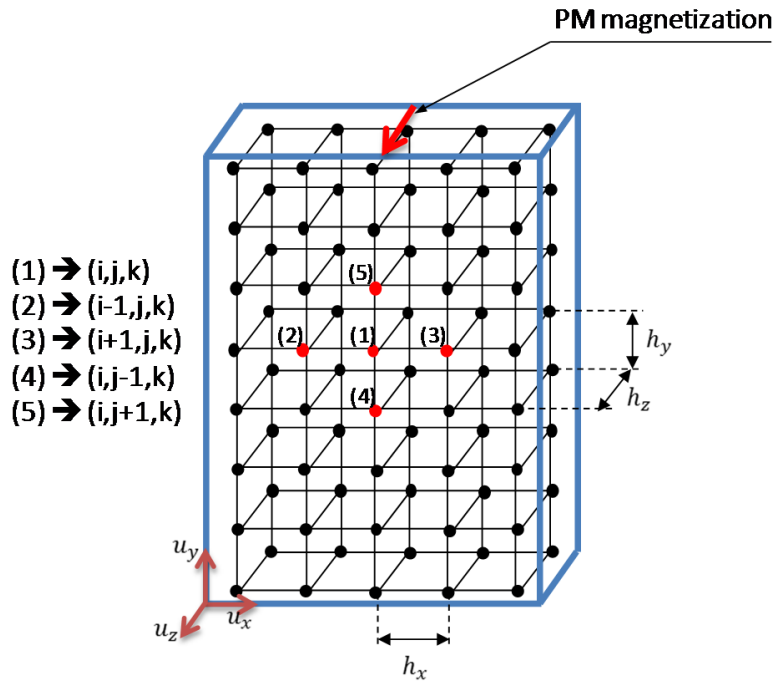

Fig. 1. PM mesh grid used for 3-D FDM.

and (5) is written

$$
e \cdot\left(E_{x_{i, j, k}}^{t}-E_{x_{i+1, j, k}}^{t}\right)=f \cdot\left(E_{y_{i, j, k}}^{t}-E_{y_{i, j+1, k}}^{t}\right),
$$

where

$$
\begin{gathered}
a=-2 \cdot(b+c) \text { with } b=e^{2} \text { and } c=f^{2} \\
\begin{array}{c}
d=-e / \Delta t \\
e=-1 / h_{x} \\
f=1 / h_{y}
\end{array}
\end{gathered}
$$

The electrical field $E_{y}$, for each layer $k$ and for each $t$, in 3-D FDM, which is defined by (11), is determined by solving the following linear equation:

$$
\left[E_{y}^{t}\right]=[\mathbf{A}]^{-1} \cdot[\mathbf{B}] \cdot\left\{\left[B_{z}^{t+\Delta t}\right]-\left[B_{z}^{t}\right]\right\}
$$

with

$$
\left[E_{y}^{t}\right]=\left[\begin{array}{c}
E_{y_{1,1, k}}{ }^{t} \\
\vdots \\
E_{y_{1, m, k}} \\
E_{y_{2,1, k}} \\
\vdots \\
E_{y_{2, m, k}}^{t} \\
\vdots \\
\vdots \\
E_{y_{n, 1, k}} \\
\vdots \\
E_{y_{n, m, k}{ }^{t}}
\end{array}\right]
$$




$$
\begin{aligned}
& {\left[B_{z}^{t}\right]=\left[\begin{array}{c}
B_{z_{1,1, k}}^{t} \\
\vdots \\
B_{z_{1, m, k}}^{t} \\
B_{z_{2,1, k}}^{t} \\
\vdots \\
B_{z 2, m, k}^{t} \\
\vdots \\
\vdots \\
B_{z_{n, 1, k}}^{t} \\
\vdots \\
B_{z_{n, m, k}}^{t}
\end{array}\right] \text { and }\left[B_{z}^{t+\Delta t}\right]=\left[\begin{array}{c}
B_{z_{1,1, k}}^{t+\Delta t} \\
\vdots \\
B_{z_{1, m, k}}^{t+\Delta t} \\
B_{z_{2,1, k}}^{t+\Delta t} \\
\vdots \\
B_{z_{2, m}}^{t+\Delta t} \\
\vdots \\
\vdots \\
B_{z_{n, 1, k}}^{t+\Delta t} \\
\vdots \\
B_{z_{n, m, k}}^{t+\Delta t} \\
\end{array}\right]} \\
& {[\mathbf{A}]=\left[\begin{array}{cccc}
1 & 2 & \cdots & n \\
{[\alpha]_{m, m}} & {[\beta]_{m, m}} & & 0 \\
{[\beta]_{m, m}} & \ddots & \ddots & \\
& \ddots & \ddots & {[\beta]_{m, m}} \\
0 & & {[\beta]_{m, m}} & {[\alpha]_{m, m}}
\end{array}\right] \begin{array}{c}
1 \\
2 \\
\vdots \\
n
\end{array}} \\
& {[\mathbf{B}]=\left[\begin{array}{cccc}
1 & 2 & \cdots & n \\
{\left[\gamma^{+}\right]_{m, m}} & {\left[\gamma^{-}\right]_{m, m}} & & 0 \\
& \ddots & \ddots & \\
& & \ddots & {\left[\gamma^{-}\right]_{m, m}} \\
0 & & & {\left[\gamma^{+}\right]_{m, m}}
\end{array}\right] \begin{array}{c}
1 \\
\vdots \\
n
\end{array}}
\end{aligned}
$$

in which

$$
[\delta]_{m, m}=f \cdot\left[\begin{array}{cccc}
1 & -1 & & 0 \\
& \ddots & \ddots & \\
& & \ddots & -1 \\
0 & & & 1
\end{array}\right]
$$

3) 3-D Eddy-Current Losses in the PMs: The instantaneous 3-D PM eddy-current losses $p_{m}$ are given by:

$$
p_{m}=\iiint \frac{J^{2}}{\sigma_{m}} \cdot d V
$$

Substituting (1) in (16), and by using the results of (14) and (15), the 3-D eddy-current losses of a PM, for each time $t$, can be obtained by:

$$
p_{m}=V_{m} \cdot \sum_{i=1}^{n} \sum_{j=1}^{m} \sum_{k=1}^{l}\left[\sigma_{m} \cdot\left(E_{x_{i, j, k}}^{2}+E_{y_{i, j, k}}^{2}\right)\right]
$$

in which

$$
\begin{gathered}
{[\alpha]_{m, m}=\left[\begin{array}{cccc}
a & c & & 0 \\
c & \ddots & \ddots & \\
& \ddots & \ddots & c \\
0 & c & a
\end{array}\right]} \\
{[\beta]_{m, m}=b \cdot[I]_{m, m}} \\
{\left[\gamma^{ \pm}\right]_{m, m}= \pm d \cdot[I]_{m, m}}
\end{gathered}
$$

where $[I]_{*, *}$ is the identity matrix of $* \times *$, and $[n \times m \times l]$ represents the $3-\mathrm{D}$ grid discretization.

The electrical field $E_{x}$, for each layer $k$ and for each $t$, in 3-D FDM, which is defined by (12), is determined by solving the following linear equation:

$$
\left[E_{x}^{t}\right]=[\mathbf{C}]^{-1} \cdot[\mathbf{D}] \cdot\left[E_{y}^{t}\right]
$$

with

$$
\begin{gathered}
{\left[E_{x}^{t}\right]=\left[\begin{array}{c}
E_{x_{1,1, k}}^{t} \\
\vdots \\
E_{x_{1, m, k}}^{t} \\
E_{x_{2,1, k}}^{t} \\
\vdots \\
E_{x_{2, m, k}}^{t} \\
\vdots \\
\vdots \\
E_{x_{n, 1, k}}^{t} \\
\vdots \\
E_{x_{n, m, k}}^{t}
\end{array}\right]} \\
{[\mathbf{C}]=\frac{e}{d} \cdot[\mathbf{B}]}
\end{gathered}
$$

where $V_{m}$ is the volume of a PM.

The average 3-D total PMs eddy-current losses $P_{m}$, over an electrical cycle $T=2 \pi / \omega$, can be defined by:

$$
P_{m}=2 p \cdot\left\langle p_{m}\right\rangle=\frac{2 p}{T} \int_{0}^{T} p_{m} \cdot d t
$$

where $p$ is the number of pole pairs.

\section{APPLICATION OF 3-D NHM TO AXIAL-FLUX PMSMS}

\section{A. Axial-Flux SPM Machine}

1) Description of the machine: The axial-flux SPM machine studied has 24-slots/16-poles (i.e. fractional-slot number) with double-stator and single-rotor (i.e., Kaman type). This studied case is supplied by sinusoidal current waveform.

The stators have a non-overlapping winding with double layer (i.e., all teeth wound type). The two stators are connected in parallel. The coils for each stator are connected in parallel with 8 paths. The 3 -phase windings are star-connected. The winding schematic is depicted in Fig. 2(a). The core of two stators is made by rolling magnetic steel sheets. The rotor is made of non-magnetic material. The PMs considered are NdFeB magnets.

The 24-slots/16-poles axial-flux SPM machine has been advanced FEM based numerical field analysis program [60]. The parameters of the machine have been sent to 3-D FEM preprocessor in the application "Transient Magnetic 3-D" (i.e., magneto-dynamical 3-D FEM) considering the current penetration effect in order to determine the 3-D PM set up using Cedrat's Flux3D software package, an 

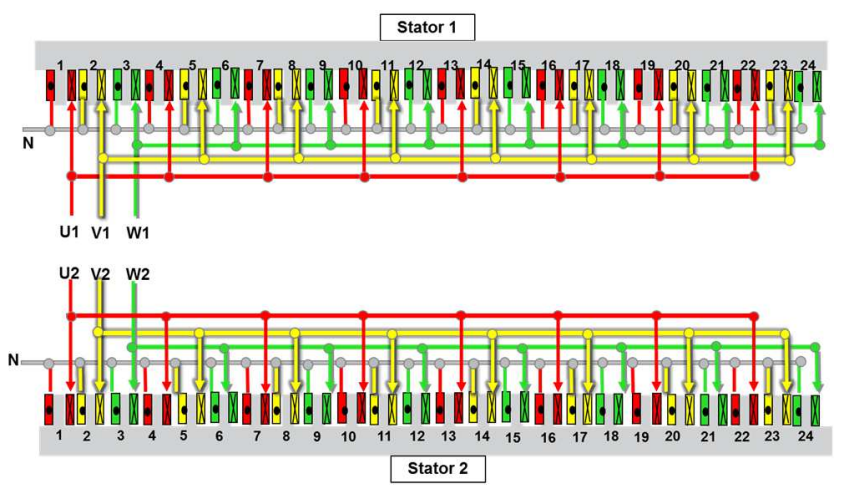

(a)

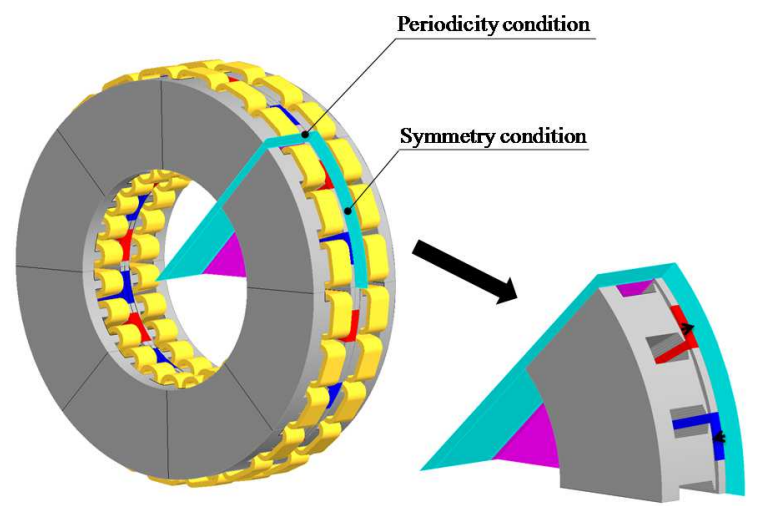

(b)

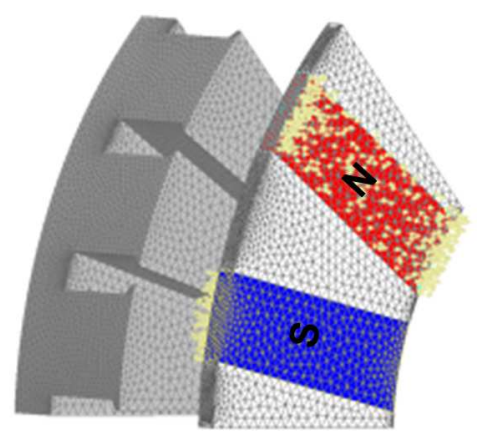

(c)

Fig. 2. Axial-flux PMSM (24-slots/16-poles) studied: (a) non-overlapping winding, (b) reduced SPM machine, and (c) mesh.

eddy-current losses. The complete machine and the boundary conditions for axial-flux SPM machine are presented in Fig. 2(b). Due to the boundary conditions (i.e., periodicity and symmetry conditions), the SPM machine can be reduced into 3-slots/2-poles, one-stator and halfrotor. The mesh (with 317,218 second order elements) of the machine is illustrated in Fig. 2(c).This leads to reduce the calculation time. The main parameters of the axial-flux SPM machine are given in TABLE III [see Appendix].

2) Results and Comparison with the Transient 3-D FEM: The distribution of PM eddy-current densities is shown in Fig. 3. It can be seen that the eddy-currents circulate in loops inside the PM volume. Thus, the current density has only two components the PM local axis system, i.e., $\vec{J}=\left\{J_{x}, J_{y}, 0\right\}$. The assumption $\vec{E}=\left\{E_{x}, E_{y}, 0\right\}$ is then confirmed [see II. A.].

Fig. 4 shows the instantaneous and average 3-D eddycurrent losses of a PM which are calculated for the following operating points: i) $200 \mathrm{Nm}$ @ 1,000 rpm [see Fig. 4(a)], and ii) $50 \mathrm{Nm}$ @ 6,000 rpm [see Fig. 4(b)]. The losses are determined with the 3-D NHM and the transient 3-D FEM. For the 3 -D NHM, the PM discretization is $[8 \times 8 \times 2]$. The different values of average 3-D total PMs eddy-current losses are reported in TABLE I. It can be seen that the 3-D PM eddy-current losses calculation method is very efficient in terms of computation time and that it gives accurate results comparing to transient 3-D FEM. The computation time is divided by 11 and the error is less than $9 \%$. It can be noted that the difference between 3-D NHM and transient 3-D FEM increases with the frequency because of the skin effect [see Fig. 4]. However, the results obtained with the proposed technique are accurate for the considered operating frequency range (i.e., 6,000 rpm corresponding to $800 \mathrm{~Hz}$ ).

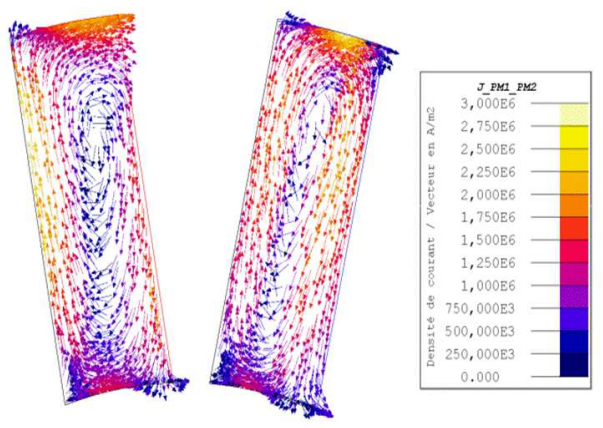

Fig. 3. PM eddy-current density loops for axial-flux SPM machine.

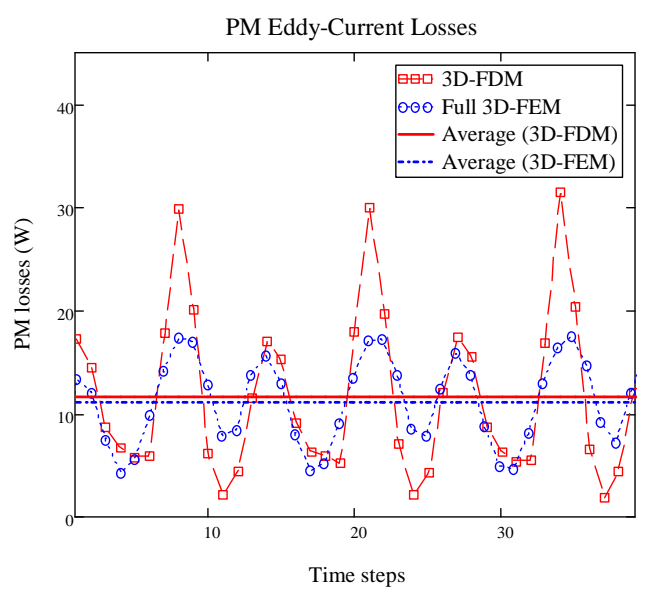

(a)

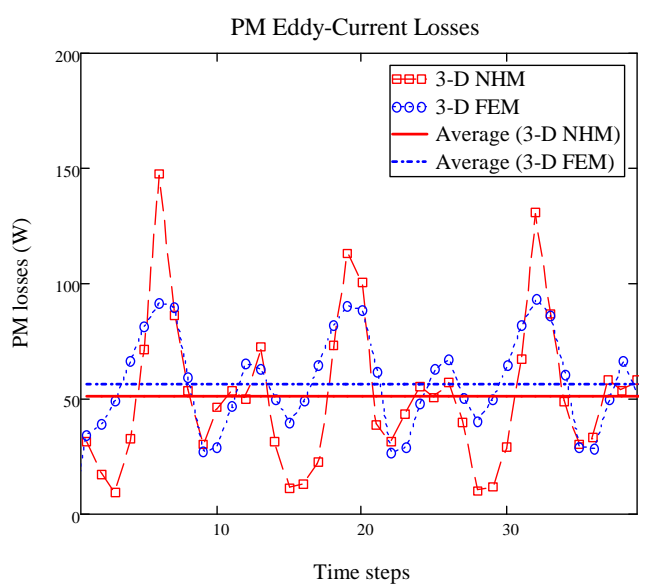

(b)

Fig. 4. 3-D PM eddy-current losses of a PM for axial-flux SPM machine for: (a) $200 \mathrm{Nm} @ 1,000 \mathrm{rpm}$, and (b) $50 \mathrm{Nm} @ 6,000 \mathrm{rpm}$. 
TABLE I

COMPARISON BETWEEN 3-D NHM AND 3-D FEM FOR AXIAL-FLUX SPM MACHINE.

\begin{tabular}{ccccc}
\hline \hline \multirow{2}{*}{$\begin{array}{c}\text { Operating } \\
\text { points }\end{array}$} & \multicolumn{2}{c}{ PM total losses [W] } & \multicolumn{2}{c}{ Computation time } \\
\cline { 2 - 5 } & 3-D NHM & $\begin{array}{c}\text { Transient } \\
\text { 3-D FEM }\end{array}$ & 3-D NHM & $\begin{array}{c}\text { Transient } \\
\text { 3-D FEM }\end{array}$ \\
\hline $\begin{array}{c}200 \mathrm{Nm} \\
1,000 \mathrm{rpm} \\
50 \mathrm{Nm}\end{array}$ & 186.8 & 177.7 & $1 \mathrm{~h}$ & $11 \mathrm{~h}$ \\
$6,000 \mathrm{rpm}$ & 823 & 903 & & \\
\hline \hline
\end{tabular}

\section{B. Axial-Flux IPM Machine}

1) Description of the machine: The axial-flux IPM machine studied has 24-slots/16-poles (i.e. fractional-slot number) with double-stator and single-rotor (i.e., Kaman type). This studied case is supplied by sinusoidal current waveform.

The winding distribution is similar to axial-flux SPM machine. It is described in Fig. 5(a). The core of two stators is made by rolling magnetic steel sheets. The rotor is different from the SPM 24-slots/16-poles presented before. Indeed, the PMs are embedded in the rotor core, made by rolling magnetic steel sheets. The PMs considered are $\mathrm{NdFeB}$ magnets.

As for the axial-flux SPM machine, the parameters have been sent to magneto-dynamical 3-D FEM. The complete machine and the boundary conditions for axial-flux IPM machine are presented in Fig. 5(b). Due to the boundary conditions (i.e., periodicity and Dirichlet conditions), the IPM machine can be reduced into 3-slots/2-poles, onestator and half-rotor. The mesh (with 786,152 second order elements) of the machine is illustrated in Fig. 5(c). This leads to reduce the calculation time. The main parameters of the axial-flux IPM machine are given in TABLE III [see Appendix].

2) Results and Comparison with the Transient 3-D FEM: In Fig. 6, it can be seen that the eddy-currents circulate in loops inside the PM, which confirms the assumption of neglecting the electric field component according the PM magnetization.

Fig. 7 shows the instantaneous and average 3-D eddycurrent losses of a PM which are calculated for the following operating points: i) $200 \mathrm{Nm} @ 1,000 \mathrm{rpm}$ [see Fig. 7(a)], and ii) $50 \mathrm{Nm}$ @ 6,000 rpm [see Fig. 7(b)]. The losses are determined with the 3-D NHM and the transient 3-D FEM. For the 3-D NHM, the PM discretization is $[4 \times 8 \times 2]$. The different values of average 3 -D total PMs eddy-current losses are reported in TABLE II. The 3-D PM eddy-current losses calculated by the proposed method are similar to results obtained by 3-D FEM. It is interesting to note that the error is less than $12 \%$. In the case of axialflux IPM machine, the calculation time with 3D-FEA is divided by 25 . This is due to the increase of convergence time of the non-linear system (i.e., the convergence time of Newton-Raphson algorithm) for transient 3-D FEM. Indeed, the increase of the convergence time is more significant with highly non-linear machines, such in the axial-flux IPM machine studied. The skin effect is less important than for axial-flux SPM machine. Moreover, from TABLE I and TABLE II, it may also be noted that, for the same operating point, that the average 3-D total PMs eddy-current losses were reduced by embedding PM in the rotor core.
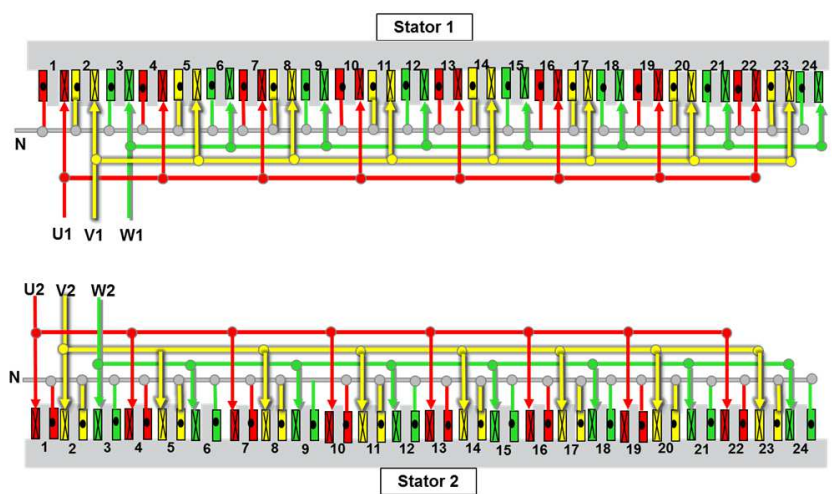

(a)

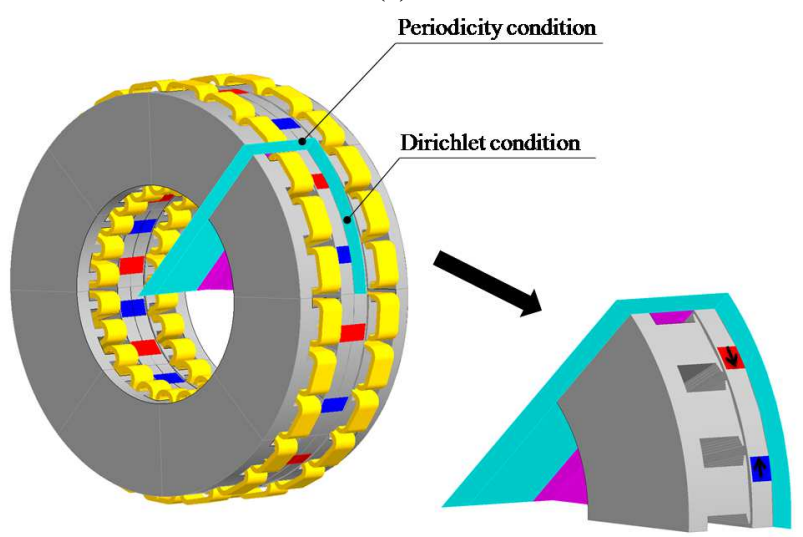

(b)

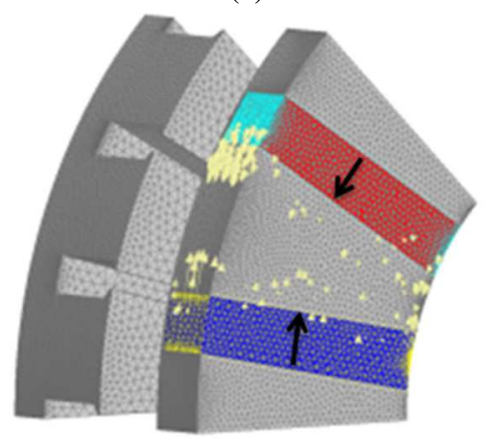

(c)

Fig. 5. Axial-flux PMSM (24-slots/16-poles) studied: (a) non-overlapping winding, (b) reduced IPM machine, and (c) mesh.

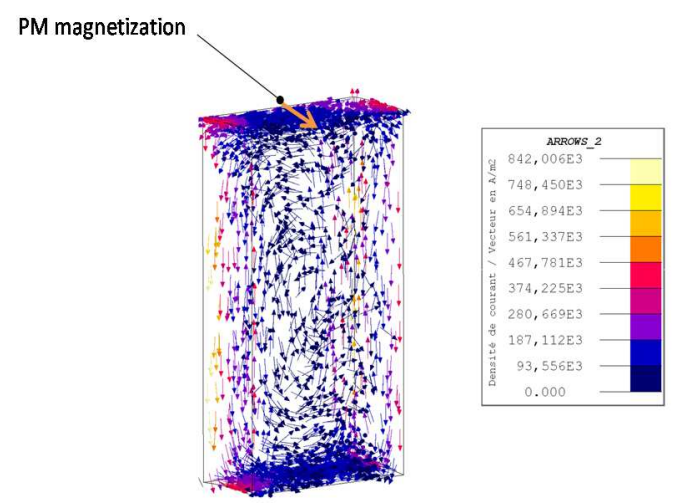

Fig. 6. PM eddy-current density loops for axial-flux IPM machine. 


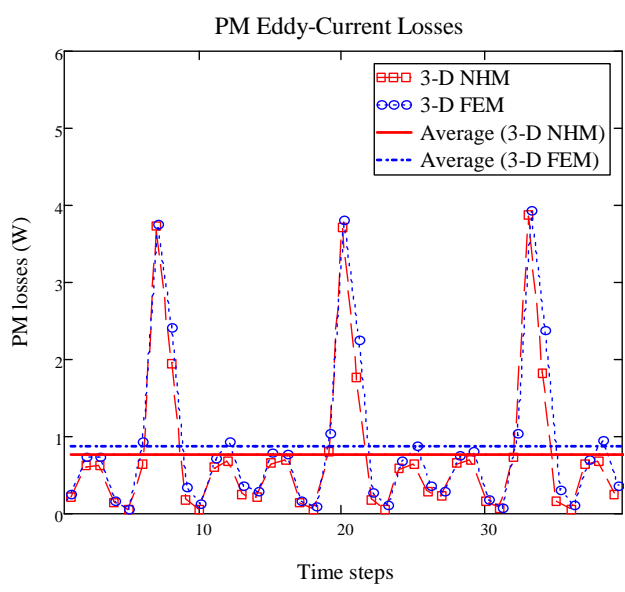

(a)

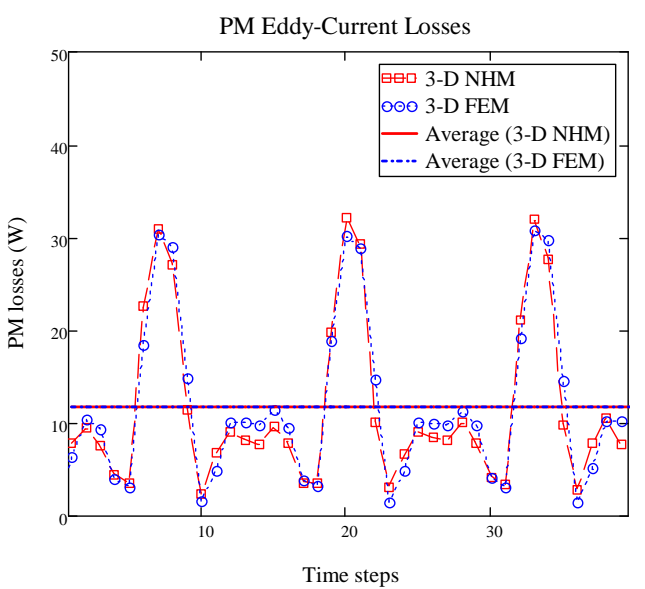

(b)

Fig. 7. 3-D PM eddy-current losses for axial-flux IPM machine for: (a) $200 \mathrm{Nm} @ 1,000 \mathrm{rpm}$, and (b) $50 \mathrm{Nm} @ 6,000 \mathrm{rpm}$.

TABLE II

COMPARISON BETWEEN 3-D NHM AND 3-D FEM FOR AXIAL-FLUX IPM MACHINE.

\begin{tabular}{ccccc}
\hline \hline \multirow{2}{*}{$\begin{array}{c}\text { Operating } \\
\text { points }\end{array}$} & \multicolumn{2}{c}{ PM total losses [W] } & \multicolumn{2}{c}{ Computation time } \\
\cline { 2 - 5 } & 3-D NHM & $\begin{array}{c}\text { Transient } \\
\text { 3-D FEM }\end{array}$ & 3-D NHM & $\begin{array}{c}\text { Transient } \\
\text { 3-D FEM }\end{array}$ \\
\hline $\begin{array}{c}200 \mathrm{Nm} \\
1,000 \mathrm{rpm}\end{array}$ & 12.2 & 13.9 & & \\
$50 \mathrm{Nm}$ & 187 & 188 & $2 \mathrm{~h} 20 \mathrm{mn}$ & $58 \mathrm{~h}$ \\
$6,000 \mathrm{rpm}$ & & & & \\
\hline \hline
\end{tabular}

\section{CONCLUSION}

The eddy-current losses are generated in PMs of PMSMs due to the spatio-temporal harmonics of the armature reaction and/or because of the presence of stator slots. The computation of the eddy-current losses in PMs is necessary during the design process of the machine to avoid high temperature and consequently the irreversible demagnetization phenomenon. The calculation of these losses is a 3-D problem by its nature, because the eddycurrents are circulating in loop inside the PM volume. The most accurate models are the 3-D FEM. However, these methods are very time and memory consuming. In order to reduce the computation time, hybrid methods can be developed.

A 3-D NHM for PM eddy-current losses calculation in axial-flux PMSMs (i.e., surface-PM and interior-PM types) has been presented. Comparing to transient 3-D FEM, the results obtained with 3-D NHM are accurate and the calculation time is divided by 11 for the axial-flux SPM machine and by 25 for the axial-flux IPM machine. The error between the 3-D NHM and transient 3-D FEM is less than $12 \%$. For a same operating point, it is interesting to note that the 3-D total PMs eddy-current losses are reduced by embedding PM in the rotor core (i.e., for the axial-flux IPM machine). Moreover, the skin effect is less important than for axial-flux SPM machine.

The PM magnetic flux density, used for the PM losses calculation, has been determined by the multi-static 3-D FEM at resistance-limited. Nevertheless, it should be noted that the PM magnetic flux density can be obtained by analytical or semi-analytical (i.e., subdomain method or magnetic equivalent circuit) methods. This study with other PM shapes (e.g., trapezoidal or circular) will be our future work. 


\section{APPENDIX}

TABLE III

PARAMETERS OF THE AXIAL-FluX SPM AND IPM MACHINES (24-SLOTS/16-POLES).

\begin{tabular}{|c|c|c|c|c|c|}
\hline \multirow[b]{2}{*}{ Parameters } & \multirow[b]{2}{*}{ Symbols } & \multicolumn{3}{|c|}{ Values } & \multirow{2}{*}{ Units } \\
\hline & & SPM & & IPM & \\
\hline Number of slots & $Q_{s}$ & & 24 & & - \\
\hline Number of pole pairs & $p$ & & 8 & & - \\
\hline Number of layers & $N_{L}$ & & 2 & & - \\
\hline Number of series turns per layer-slot & $N_{s t s}$ & & 80 & & - \\
\hline Number of series turns per phase & $N_{s t p}$ & & 80 & & - \\
\hline Number of the machine parallel paths & $N_{p p}$ & & 16 & & - \\
\hline Number of parallel paths per stator & $N_{p p s}$ & & 8 & & - \\
\hline Maximum current for the sinusoidal waveform for $N=1,000 \mathrm{rpm}$ & $I_{s \max }$ & 260 & & 255 & $A$ \\
\hline Maximum current for the sinusoidal waveform for $N=6,000 \mathrm{rpm}$ & $I_{s \max }$ & 70 & & 65 & $A$ \\
\hline Outer diameter & $D_{\text {out }}$ & & 240 & & $m m$ \\
\hline Inner diameter & $D_{\text {in }}$ & & 130 & & $m m$ \\
\hline Axial length of the PMs & $L_{m}$ & 8 & & 20 & $m m$ \\
\hline Width of the PMs & $W_{m}$ & 20 & & 7 & $m m$ \\
\hline Axial length of the rotor & $L_{\text {rot }}$ & 8 & & 23 & $m m$ \\
\hline Radial length of the PMs & $h_{m}$ & & 55 & & $m m$ \\
\hline Stator slot depth & $d_{s l}$ & & 22 & & $m m$ \\
\hline Stator slot opening & $W_{s l}$ & & 12 & & $m m$ \\
\hline Stator slot-isthmus width & $W_{s i}$ & & 4 & & $m m$ \\
\hline Stator yoke thickness & $L_{s y}$ & & 10 & & $m m$ \\
\hline $\begin{array}{l}\text { Mechanical angular position between the rotor and the stator at the instant } \\
\mathrm{t}=0 \mathrm{sec}\end{array}$ & $\Theta_{r s 0}$ & -4 & & -15 & deg. \\
\hline Axial length of the motor & $L_{m o t}$ & 78.4 & & 95.4 & $m m$ \\
\hline Relative magnetic permeability of the PMs & $\mu_{r m}$ & & 1.05 & & - \\
\hline Operating temperature of the PMs & $T_{m}$ & & 100 & & ${ }^{\circ} \mathrm{C}$ \\
\hline Residual flux density of the PMs at $T_{m}$ & $B_{r m}$ & & 1.15 & & $T$ \\
\hline Electrical conductivity of the PMs at $T_{m}$ & $\sigma_{m}$ & & $0.7 \times 10^{6}$ & & $S / m$ \\
\hline Volumetric mass density of the PMs & $\rho_{v m}$ & & 7500 & & $\mathrm{~kg} / \mathrm{m}^{3}$ \\
\hline
\end{tabular}




\section{ACKNOWLEDGMENT}

This work was supported by the RENAULT-SAS, Guyancourt, France.

\section{REFERENCES}

[1] Z.Q. Zhu, "Fractional Slot Permanent Magnet Brushless Machines and Drives for Electric and Hybrid Propulsion Systems," in Proc. EVER, Monaco, March 26-29, 2009.

[2] F. Dubas, and C. Espanet, "Semi-analytical Solution of 2-D rotor Eddy-Current Losses due to the Slotting Effect in SMPMM," in Proc. COMPUMAG, Florianopolis, Brasil, Nov. 22-26, 2009.

[3] F. Dubas, C. Espanet, and A. Miraoui, "Field Diffusion Equation in High-Speed Surface Mounted Permanent Magnet Motors, Parasitic Eddy-Current Losses," in Proc. ELECTROMOTION, Lausanne, Switzerland, Sep. 27-29, 2005.

[4] Z.Q. Zhu, K. Ng, N. Schofield, and D. Howe, "Improved Analytical Modelling of Rotor Eddy Current Loss in Brushless Machines Equipped with Surface-Mounted Permanent Magnets," IEE Proc.Electr. Power Appl., vol. 151, no. 6, pp. 641-650, Nov. 2004.

[5] F. Dubas, and A. Rahideh, "2-D Analytical PM Eddy-Current Loss Calculations in Slotless PMSM Equipped with Surface-Inset Magnets," IEEE Trans. on Magn., vol. 50, no. 3, 6300320 , March 2014.

[6] O.D.L. Barriere, S. Hlioui, H.B. Ahmed, and M. Gabsi, "An Analytical Model for the Computation of No-Load Eddy Current Losses in the Rotor of a Permanent Magnet Synchronous Machine,' IEEE Trans. on Magn., DOI: 10.1109/TMAG.2013.2257825, 2013, In Press.

[7] B.C. Mecrow, A.G. Jack, and J.M. Mastermann, "Determination of Rotor Eddy Current Losses in Permanent Magnet Machines," in Proc. IEMDC, Oxford, UK, Sept. 27-29, 1993.

[8] J.L. Kirtley, M. Tolikas, J.H. Lang, C.W. Ng, and R. Roche, "Rotor Loss Models for High Speed PM Motor-Generators," in Proc. ICEM, Istanbul, Turkey, Sept. 02-04, 1998.

[9] P. Sergeant, and A. Van den Bossche, "Segmentation of Magnets to Reduce Losses in Permanent-Magnet Synchronous Machines," IEEE Trans. on Magn., vol. 44, no. 11, pp. 4409-4412, Nov. 2008.

[10] K. Yamazaki, and Y. Fukushima, "Effect of Eddy-Current Loss Reduction by Magnet Segmentation in Synchronous Motors with Concentrated Windings," in Proc. ICEMS, Tokyo, Japan, Nov. 15-18, 2009.

[11] K. Yamazaki, M. Shina, Y. Kanou, M. Miwa, and J. Hagiwara, "Effect of Eddy-Current Loss Reduction by Segmentation of Magnets in Synchronous Motors: Difference Between Interior and Surfaces Types," IEEE Trans. on Magn., Vol. 45, no. 10, Oct. 2009.

[12] J. Li, D-W. Choi, C-H. Cho, D-H. Koo, and Y-H. Cho, "Eddy-Current Calculation of Solid Components in Fractional Slot Axial Flux Permanent Magnet Synchronous Machines," IEEE Trans. on Magn. vol. 47, no. 10 , pp. 4254-4257, Oct. 2011

[13] J. Pyrhonen, H. Jussila, Y. Alexandrova, P. Rafajdus, and J. Nerg, "Harmonic Loss Calculation in Rotor Surface Permanent Magnets: New Analytic Approach," IEEE Trans. on Magn., vol. 48, no. 8, pp. 2358-2366, Aug. 2012.

[14] H. Vansompel, P. Sergeant, and L. Dupré, "Effect of segmentation on Eddy-Current Loss in Permanent-Magnets of Axial-Flux PM Machines using a Multilayer-2D - 2D Coupled Model," in Proc. ICEM, Marseille, France, Sept. 02-05, 2012.

[15] K. Yamazaki, Y. Kato, T. Ikemi, and S. Ohki, "Reduction of Rotor Losses in Multilayer Interior Permanent-Magnet Synchronous Motors by Introducing Novel Topology of Rotor Flux Barriers," IEEE Trans. on Ind. Appl., vol. 50, no. 5, pp. 3185-3193, Sept./Oct. 2014.

[16] F. Caricchi, F.G. Capponi, F. Crescimbini, and L. Solero, "Experimental study on reducing cogging torque and no-load power loss in axial-flux permanent-magnet machines with slotted winding," IEEE Trans. on Ind. Appl., vol. 40, no. 4, pp. 1066-1075, JulyAug. 2004.

[17] L. Alberti, E. Fornasiero, N. Bianchi, and S. Bolognani, "Rotor Losses Measurements in an Axial Flux Permanent Magnet Machine," IEEE Trans. on Ener. Conv., vol. 26, no. 2, pp. 639-645, June 2011.

[18] D. Liu, A. Jassal, H. Polinder, and J.A. Ferreira, "Validation of Eddy Current Loss Models for Permanent Magnet Machines with Fractional-Slot Concentrated Windings," in Proc. IEMDC, Chicago, Illinois (USA), May 12-15, 2013.

[19] X. Yang, D. Patterson, J. Hudgins, and J. Colton, "FEA estimation and experimental validation of solid rotor and magnet eddy current loss in single-sided axial flux permanent magnet machines," in Proc. ECCE, Denver, CO, USA, Sept. 15-19, 2013.

[20] J. Wang, K. Atallah, R. Chin, W.M. Arshad, and H. Lendenmann, "Rotor Eddy-Current Loss in Permanent-Magnet Brushless AC Machines," IEEE Trans. on Magn., vol. 46, no. 7, pp. 2701-2707, July 2010 .

[21] M. Mirzaei, A. Blinder, B. Funieru, and M. Susic, "Analytical Calculations of Induced Eddy Currents Losses in the Magnets of Surface Mounted PM Machines With Consideration of Circumferential and Axial Segmentation Effects," IEEE Trans. on Magn., vol. 48, no. 12, pp. 4831-4841, Dec. 2012.

[22] Y. Kawase, T. Ota, and H. Fukunaga, "3-D Eddy Current Analysis in Permanent Magnet of Interior Permanent Magnet Motors," IEEE Trans. on Magn., vol. 36, no. 4, pp. 1863-1866, July 2000.

[23] W-Y. Huang, A. Bettayeb, R. Kaczmarek, and J-C. Vannier, "Optimization of Magnet Segmentation for Reduction of EddyCurrent Losses in Permanent Magnet Synchronous Machine," IEEE Trans. on Energy. Conv., vol. 25, no. 2, pp.381-387, June 2010.

[24] M. Mirzaei, A. Blinder, and C. Deak, "3D Analysis of Circumferential and Axial Segmentation Effect on Magnet Eddy Current Losses in Permanent Magnet Synchronous Machines with Concentrated Windings," in Proc. ICEM, Rome, Italy, Sept. 06-08, 2010.

[25] F. Martin, M.E.H. Zaïm, A. Tounzi, and N. Bernard, "Improved Analytical Determination of Eddy Current Losses in Surface Mounted Permanent Magnets of Synchronous Machines," IEEE Trans. on Magn., vol. 50, no. 6, 8201409, June 2014.

[26] K. Yoshida, K. Kesamaru, and Y. Hita, "Eddy Currents Analysis of Surface-Mounted-PMSM by Finite Element Method," in Proc. ICEM, Istanbul, Turkey, Sept. 02-04, 1998.

[27] A. Bettayeb, X. Jannot, and J.C Vannier, "Analytical Calculation of Rotor Magnet Eddy-Current Losses for High Speed IPMSM," in Proc. ICEM, Rome, Italy, Sept. 06-08, 2010.

[28] R. Benlamine, S-A. Randi, D. Lhotellier, F. Dubas, and C. Espanet, "Design of an Axial-Flux Interior Permanent-Magnet Synchronous Motor for Automotive Application: Performance Comparison with Electric Motors used in EVs and HEVs," in Proc. VPPC, Coimbra, Portugal, Oct. 27-30, 2014.

[29] M. Nakano, H. Kometani, and M. Kawamura, "A Study on EddyCurrent Losses in Rotors of Surface Permanent-Magnet Synchronous Machines," IEEE Trans. on Magn., vol. 42, no. 2, pp. 429-435, March/April 2006.

[30] M.R. Shah, and A.M. EL-Refaie, "Eddy-Current Loss Minimization in Conducting Sleeves of Surfaces PM Machine Rotors With FractionalSlot Concentrated Armature Windings by Optimal axial Segmentation and Copper Cladding," IEEE Trans. on Ind. Appl., vol. 45, no. 2, pp. 720-728, March/April 2009.

[31] A.A. Qazalbash, S.M. Sharkh, N.T. Irenji, R.G. Wills, and M.A. Abusara, "Rotor Eddy Current Power Loss in Permanent Magnet Synchronous Generators Feeding Uncontrolled Rectifier Loads," IEEE Trans. on Magn., vol. 50, no. 6, 8201409, June 2014.

[32] A.A. Qazalbash, S.M. Sharkh, N.T. Irenji, R.G. Wills, and M.A. Abusara, "Calculation of No-Load Rotor Eddy-Current Power Loss in PM Synchronous Machines," IEEE Trans. on Magn., vol. 50, no. 9, 7027308, Sept. 2014.

[33] A. Tariq, C.E. Nino-Baron, and E.G. Strangas, "Iron and Magnet Losses and Torque Calculation of Interior Permanent Magnet Synchronous Machines Using Magnetic Equivalent Circuit," IEEE Trans. on Magn. , vol. 46, no. 12, pp. 4073-4080, Dec. 2010.

[34] B. Aslan, E. Semail, and J. Legranger, "Analytical Model of Magnet Eddy-Current Volume Losses in Multi-phase PM Machines with Concentrated Winding," in Proc. ECCE, Raleigh, North Carolina, Sept. 15-20, 2012.

[35] A. Hemeida, and P. Sergeant, "Analytical Modeling of Eddy Current Losses in Axial Flux PMSM Using Resistance Network," in Proc. ICEM, Berlin, Germany, Sept. 02-05, 2014.

[36] J. Li, D-W. Choi, D-H. Son, and Y-H. Cho, "Effects of MMF Harmonics on Rotor Eddy-current Losses for Inner-Rotor Fractional Slot Axial Flux Permanent Magnet Synchronous Machines," IEEE Trans. on Magn., vol. 48, no. 2, pp. 839-842, Feb. 2012.

[37] T.J.E. Miller, M.I. McGilp, and K.W. Klontz, "Approximate Methods for Calculating Rotor Losses in Permanent-Magnet Brushless Machines," in Proc. IEMDC, Miami, Florida, May 03-06, 2009.

[38] S. Ruoho, T. Santa-Nokki, J. Kolehmaien, and A. Arkkio, "Modeling Magnet Length In 2-D Finite-Element Analysis of Electric Machines," IEEE Trans. on Magn., vol. 45, no. 8, pp. 3114-3120, August 2009.

[39] T. Fadriansyah, T.D. Strous, and H. Polinder, "Axial Segmentation and Magnets Losses of SMPM Machines using 2D FE Method," in Proc. ICEM, Marseille, France, Sept. 02-05, 2012.

[40] P. Zhang, G.Y. Sizov, J. He, D.M. Ionel, and N. Dernerdash, "Calculation of Magnet Losses In Concentrated-Winding Permanent 
Magnet Synchronous Machines Using a Computationally Efficient Finite Element Method," in Proc. ECCE, Raleigh, North Carolina, Sept. 15-20, 2012.

[41] H. Vansompel, P. Sergeant, and L. Dupré, "A Multilayer 2-D - 2-D Coupled Model for Eddy Current Calculation in the Rotor of an AxialFlux PM Machine," IEEE Trans. on Energy Conv., vol. 27, no. 3, pp. 784-791, Sept. 2012.

[42] T. Okisu, D. Matsuhashi, Y. Gao, and K. Muramatsu, "Coupled 2-D and 3-D Eddy Current Analyses for Evaluating Eddy Current Loss of a Permanent Magnet in Surface PM Motors," IEEE Trans. on Magn., vol. 48, no. 11, Nov. 2012.

[43] E.E. Kriezis, T.D. Tsiboukis, S.M. Panas, and J.A. Tegopoulos, "Eddy Currents: Theory and Applications," in Proc. IEEE, vol. 80, no. 10, pp. 1559-1589, Oct. 1992.

[44] P.M. Lindh, H.K. Jussila, M. Niemela, A. Parviainen, and J. Pyrhonen, "Comparison of Concentrated Winding Permanent Magnet Motors With Embedded and Surface-Mounted Rotor Magnets," IEEE Trans. on Magn., vol. 45, no. 5, pp. 2085-2089, May 2009.

[45] J. Schutte, J.M. Strauss, "Optimisation of a transverse flux linear PM generator using 3D Finite Element Analysis," in Proc. ICEM, Rome, Italy, Sept. 06-08, 2010.

[46] C. Espanet, C. Kieffer, A. Mira, S. Giurgea, and F. Gustin, "Optimal Design of a Special permanent Magnet Synchronous Machine for Magnetocaloric Refrigeration," in Proc. ECCE, Denver, Colorado, USA, Sept. 15-19, 2013.

[47] W. Wu, J.B. Dunlop, S.J. Collocott, and B.A. Kalan, "Design Optimization of a Switched Reluctance Motor by Electromagnetic and Thermal Finite-Element Analysis, " IEEE Trans. on Magn., vol. 39, no. 5, pp. 3334-336, Sept. 2003.

[48] M. Aydin, S. Huang, and T.A. Lipo, "Axial Flux Permanent Magnet Disc Machines: A Review," in Proc. WEMPEC, Madison, Wisconsin USA, Oct., 2004.

[49] F. Giulii Capponi, G. De Donato, and F. Caricchi, "Recent Advances in Axial-Flux Permanent-Magnet Machine Technology," IEEE Trans. on Ind. Appl., vol. 48, no. 6, pp. 2190-2205, Nov./Dec. 2012

[50] S. Kahourzade, A. Mahmoudi, H.W. Ping, and M.N. Uddin, "A Comprehension Review of Axial-Flux Permanent-Magnet Machines," Canadian Journal of Elec. and Comp. Eng., vol. 37, no. 1, pp. 19-33, 2014.

[51] Z. Chao-hui, and Y. Yang-guang, "A review of development of hybrid excitation synchronous machine," in Proc. ISIE, Dubrovnik, Croatia, June 20-23, 2005

[52] Z.Q. Zhu, and D. Howe, "Electrical Machines and Drives for Electric, Hybrid, and Fuel Cell Vehicles," in Proc. IEEE, vol. 95, no. 4, pp. 746-765, April 2007.

[53] K.T. Chau, C.C. Chan, and C. Liu, "Overview of Permanent-Magnet Brushless Drives for Electric and Hybrid Electric Vehicles," IEEE Trans. on Ind. Electronics, vol. 55, no. 6, June 2008.

[54] A.M. EL-Refaie, "Fault-Tolerant PM Machines: A Review," IET Electr. Power Appl., vol. 5, no. 1, pp. 59-74, Jan. 2011.

[55] K. Sitapati, and R. Khishnan, "Performance comparisons of radial and axial field, permanent-magnet, brushless machines," IEEE Trans. Ind. on Appl., vol. 37, no. 5, pp. 1219-1226, Sept./Oct. 2001.

[56] A. Cavagnino, M. Lazzari, F. Profumo, and A. Tenconi, "A Comparison Between the Axial Flux and the Radial Flux Structures for PM Synchronous Motors," IEEE Trans. on Ind. Appl., vol. 38, no. 6 , pp. 1517-1524, Nov./Dec. 2002

[57] J. Cros, and P. Viarouge, "Synthesis of High Performance PM Motors With Concentrated Windings," IEEE Trans. on Energy Conv., vol. 17 no. 2, pp. 248-253, June 2002.

[58] N. Bianchi, and S. Bolognani, "Design Techniques for Reducing the Cogging Torque in Surface-Mounted PM Motors," IEEE Trans. on Ind. App., vol. 38, no. 2, pp. 1259-1265, Sept./Oct. 2002.

[59] N. Bianchi, and E. Fornasiero, "Impact of MMF Space Harmonic on Rotor Losses in Fractional-Slot Permanent-Magnet Machines," IEEE Trans. on Energy Conv., vol. 24, no. 2, pp. 323-328, June 2009.

[60] "General operating instructions" - Version 11.1., Flux2D/3D, Cedrat S.A. Electrical Engineering, Grenoble, France, 2013.

\section{AUTHOR'S INFORMATION}

Raouf Benlamine ( $\mathrm{S}^{\prime} 14$ ) was born in Algiers, Algeria, in 1987. He received the engineer's degree in electrical engineering from "Ecole Nationale Polytechnique", Algiers, Algeria, in 2010, the master's degree in electrification and automotive propulsion from "Ecole Centrale de Paris", Châtenay-Malabry, France, in 2011.

He is currently pursuing Ph.D. researches with FEMTO-ST Institute (CNRS UMR 6174)/ ENERGY Department, University of Franche-Comte (UFC), France, in collaboration with Renault.

He has authored many publications and a patent about the manufacturing of axial-flux permanent magnet (PM) machines with flux-focusing. His current research interests include the modeling and the design of electromagnetic devices, in particular axial-flux and radial-flux PM synchronous machines.

Frédéric Dubas was born in Vesoul, France, on June 16, 1978. He received the Degree from the University of Franche-Comté (UFC), Vesoul and Belfort, in 2002, and the Ph.D. degree from the UFC, Belfort, in 2006, on the subject of the design and the optimization of high-speed surfacemounted permanent magnet motor (SMPMM) for the drive of a Fuel Cell (FC) air-compressor.

At the present time, he is an Associate Professor in the Franche-Comté Electronique, Mécanique, Thermique et Optique - Sciences et Technologies (FEMTO-ST) Insitute/ENERGY Department. He works with ALSTOM Transports, Ornans, and RENAULT, Guyancourt, on the modelling, the design and the optimization of electrical systems and, in particular, induction and permanent-magnet synchronous (radial and/or axial flux) machines, creative problem solving and electrical propulsion/traction.

$\mathrm{He}$ is the author of more than 50 refereed publications and a patent about the manufacturing of axial-flux PM machines with flux-focusing. Dr. Dubas received the Prize Paper Awards in the IEEE Conference Vehicle Power and Propulsion (VPPC) in 2005

Sid-Ali Randi received the degree of engineer in electrical engineering from "Ecole Nationale Polytechnique", Algiers, in 1995, and Ph.D. from "Institut National Polytechnique de Toulouse", in 2003.

He has over 15 years of experience in the design and simulation of electrical machines and electrical drives for different industrial application, especially permanent magnet machines for electric mobility. He is actually working as R\&D Engineer in the field of Electric Machines and Drives at RENAULT Simulation department.

Dominique Lhotellier has spent nearly 20 years on innovative solutions in power electronics and e-motors for affordable more electric cars.

He is currently a Senior Technology Advisor for electrical engineering in RENAULT SAS, Guyancourt, France.

Christophe Espanet (M'04) was born in Belfort, France, in 1972. He received the Laurea degree from the Ecole Normale Supérieure, Paris, France, in 1995, and the Ph.D. degree from the University of FrancheComte, Belfort, in 1999.

His Ph.D. research dealt with the design and optimization of permanentmagnet (PM) high-torque in-wheel motors.

From 1999 to 2007, he was an Associate Professor in the Laboratory of Electrical Engineering and Systems. He is currently a full Professor at the University of Franche-Comte (UFC), where he is the Head of the Team of Energy Conversion Systems Design in FEMTO-ST Institute. He is the author of more than 50 international Transactions papers and more than 60 international conferences papers. His research interests include modelling and design of electrical systems and, in particular, PM synchronous machines. 